\title{
A new leanchoiliid megacheiran arthropod from the lower Cambrian Emu Bay Shale, South Australia
}

Gregory D. Edgecombe, Diego C. García-Bellido, and John R. Paterson

Acta Palaeontologica Polonica 56 (2), 2011: 385-400 doi: http://dx.doi.org/10.4202/app.2010.0080

The Leanchoiliidae is well-known from abundant material of Leanchoilia, from the Burgess Shale and Chengjiang

Konservat-Lagerstätten. The first Australian member of the group is Oestokerkus megacholix gen. et sp. nov., described from the Emu Bay Shale (Cambrian Series 2, Stage 4), at Buck Quarry, Kangaroo Island, South Australia, and is intermediate in age between the well known leanchoiliid species from the Burgess Shale and Chengjiang. Phylogenetic analysis of "short great appendage" arthropods (Megacheira) in the context of the chelicerate stem group resolves the Australian species as sister to Burgess Shale, Utah, and Chengjiang Leanchoilia species, but most readily distinguished from Leanchoilia and Alalcomenaeus by a different telson shape, interpreted as being forked, widening distally, and with a few dorsally curved spines at the posterior angle. Leanchoiliid interrelationships are stable to alternative character weights, and Megacheira corresponds to a clade in most analyses.

Key words: Arthropoda, Megacheira, Leanchoiliidae, Oestokerkus, Leanchoilia, Alalcomenaeus, midgut glands, phylogeny, Cambrian, South Australia.

Gregory D. Edgecombe [g.edgecombe@nhm.ac.uk], Department of Palaeontology, The Natural History Museum, Cromwell Road, London SW7 5BD, UK; Diego C. García-Bellido [Diego.GBC@geo.ucm.es], Departamento de Paleontología, Instituto de Geología Económica/Instituto de Geociencias (CSIC-UCM), José Antonio Novais 2, 28040- Madrid, Spain; John R. Paterson [jpater20@une.edu.au], Division of Earth Sciences, School of Environmental and Rural Science, University of New England, Armidale, NSW 2351, Australia.

This is an open-access article distributed under the terms of the Creative Commons Attribution License (for details please see creativecommons.org), which permits unrestricted use, 
distribution, and reproduction in any medium, provided the original author and source are credited.

For Full text $(2,094.8 \mathrm{kB})$ 